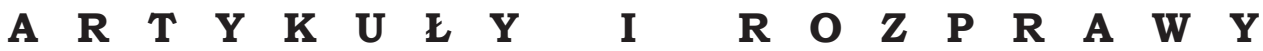

Magdalena Żabowska

DOI: 10.33896/PorJ.2021.9.1

(Uniwersytet Mikołaja Kopernika, Toruń,

e-mail: zabowska@umk.pl)

ORCID: 0000-0002-7046-7293

\section{PARENTEZA A METATEKST ${ }^{\star}$}

Parenteza jest struktura językowa, która może być interpretowana $z$ perspektywy składniowej (ze względu na jej budowę, relację względem innych składników zdania itp.) lub funkcjonalnej (rola i miejsce $\mathrm{w}$ wypowiedzeniu, typ komentarza względem tzw. podstawowej części zdania itd.). Ujęcia składniowe sa charakterystyczne dla tzw. składni tradycyjnej i strukturalnej, funkcjonalne zaś - dla koncepcji tzw. wypowiedzeniowych, ujmujących zdanie jako aktualną realizację mówienia, powiazana inherentnie ze struktura tematyczno-rematyczną. Problem metatekstowości parentezy istnieje niezależnie od przyjmowanego ujęcia. Żeby się o tym przekonać, wystarczy przywołać np. opis parentezy czasownikowej w perspektywie składniowo-strukturalnej [Moroz 2010], wypowiedzeniowej [Stępień 2014] czy diachronicznej [Kleszczowa 2015]. Wszystkie wskazane koncepcje wiąża parentezę $z$ metatekstem, jednak rozstrzygnięcia te należy traktować raczej jako arbitralne (choć poparte odpowiednią argumentacją) decyzje autorów niż rozwiązanie problemu metatekstowości parentezy. Dyskusje na temat wzajemnych relacji między parentetycznościa a metatekstowością wciąż trwaja [por. Grochowski 1983; 2007], a obecny stan wiedzy, zarówno w odniesieniu do nich samych, jak i relacji między elementami wypowiedzenia (por. zależność syntaktyczna vs kookurencja vs brak zależności), umożliwia, w moim przekonaniu, ustalenie zakresów tytułowych pojęć.

Artykuł - poza częściami przeglądowymi, w których przedstawiam najważniejsze koncepcje parentezy (składniowe oraz funkcjonalne) zawiera autorska propozycję rozróżnienia zakresu pojęć <parenteza> i <metatekst> (resp. < parentetyczność> vs <metatekstowość>), a także uporządkowania wyrażeń językowych (zarówno poszczególnych jednostek, jak i całych klas) ze względu na możliwość wystapienia w parentezie (por. elementy systemu inherentnie parentetyczne vs użycia parente-

* Praca naukowa finansowana w ramach programu Ministra Nauki i Szkolnictwa Wyższego pod nazwą „Narodowy Program Rozwoju Humanistyki” w latach 2018-2023, nr projektu 0066/NPRH6/H11/85/2018. 
tyczne wyrażeń językowych) oraz pełnienia funkcji metatekstowych. Przedstawiam także wpływ struktur parentetycznych na zmiany w języku - w odniesieniu do wykształcania się wyrażeń metatekstowych oraz ich klas w wyniku procesów leksykalizacji i gramatykalizacji.

\section{SKLADNIOWE TEORIE PARENTEZY}

Parenteza w perspektywie składniowej jest składnikiem zdania (o różnym stopniu złożoności), niepowiązanym zależnością syntaktyczną ze zdaniem głównym. $Z$ tego względu jest w zdaniu elementem nieobligatoryjnym, w łatwy sposób poddajacym się redukcji.

Ze względu na budowę zdania i rodzaj związku między parentezą a pozostała jego częścią w opisie struktur parentetycznych stosuje się terminy: zdanie wtracone [Krasnowolski 1897], wypowiedzenie zestawione, parenteza, uwaga nawiasowa [Klemensiewicz 1951; 1953], tekst prowadzacy i tekst naddany [Górny 1962], wypowiedź wtracona [Jodłowski 1976], wypowiedź główna i wyrażenie parentetyczne [Grochowski 1983], wyrażenie parentetyczne i wyrażenie główne [Moroz 2010].

\subsection{Parenteza w składni tradycyjnej}

W tradycyjnych opisach składniowych zwraca się uwagę na niejasny status gramatyczny struktur parentetycznych: ze względu na brak zależności formalnych $z$ pozostałymi składnikami zdania uznaje się, że parenteza nie należy do ścisłej struktury zdania; ponadto ciagi parentetyczne stanowia zbiór niejednorodny pod względem formy i funkcji. Przyjmuje się, że parenteza - w odróżnieniu od apozycji (w terminologii Krasnowolskiego [1897] dopowiedzeń) - nie jest struktura przynależna zdaniom pojedynczym, z kolei od przytoczenia różni się tym, że wprowadza do tekstu głównego tekst tego samego nadawcy. Wypowiedzenia wtrącone w odróżnieniu od wypowiedzeń nawiasowych, wyznaczających ubocznie jakiś szczegół należący do treści zdania - dotyczą czyjegoś sądu lub osobistej postawy mówiącego wobec treści wypowiedzi [Krasnowolski 1897; Jodłowski 1976].

Brak zwiąku składniowego między parenteza a elementami zdania podstawowego $\mathrm{w}$ ramach tego samego wypowiedzenia był opisywany jako związek logiczny [Krasnowolski 1897], skojarzeniowy związek myślowy [Klemensiewicz 1953], uboczna, drugoplanowa opinia lub postawa mówiącego wobec treści wypowiedzenia [Jodłowski 1976], redundantny komentarz o funkcji modalnej [Wróbel 1975]. Przyjmuje się, że funkcja parentezy (wypowiedzenia wtrąconego) polega na ustosunkowaniu się nadawcy względem prawdziwości treści zdania [Krasnowolski 1897], dodaniu do tekstu uwagi wypływającej ze stanowiska refleksyjnego względem treści zdania [Klemensiewicz 1953], ustosunkowaniu się autora 
do tekstu [Górny 1962]. Dodajmy, że Wojciech Górny [1962], który odróżnia tworzenie tekstu od tekstu jako produktu językowego, związek między tekstem prowadzącym a tekstem komentującym opisuje odpowiednio jako zwiazek skojarzeniowy vs zwiąek semantyczno-treściowy i formalny, którego wykładnikami są styczność tekstowa i łączność intonacyjna.

Jak pokazał M. Grochowski [1983], typologie wyrażeń parentetycznych, zarówno formalno-gramatyczne, jak i semantyczne, nie sa wyczerpujące; por. np. typy parentez wyróżnione przez Stanisława Bąbę i Stanisława Mikołajczaka [1975]: (a) parentezy akcesoryjne, (b) komentujace i dopowiadajace, (c) z przytoczeniem, (d) z uwaga chronologiczna lub dygresja, (e) z konstrukcjami emfatyczno-emocjonalnymi, (f) konkretyzujące, (g) wariantujące; por. również Klemensiewicz 1951; Bąba, Mikołajczak 1973; Makarski 1971; Marcjanik 1978.

\subsection{Parenteza w składni strukturalnej}

W składni strukturalnej przyjmuje się, że parenteza jest struktura językowa niesamodzielna wypowiedzeniowo, w zdaniu stanowi składnik nieobligatoryjny i niedeterminowany, zarazem determinuje istnienie struktury podstawowej - wymaga obligatoryjnie wyrażenia głównego [Moroz 2010; por. też Górny 1962]. Może być ciagiem o dowolnym stopniu złożoności (zdaniem, konstrukcją składniowa, składnikiem konstrukcji składniowej). Typ związku między wyrażeniem parentetycznym (WP) a wypowiedzeniem głównym (WG) określa się jako relację kookurencji [por. Wajszczuk 2005]. Ze względu na typ wyrażenia głównego, z którym wyrażenie parentetyczne wchodzi w relację, wyróżnia się kookurencje wypowiedzeniowa i składnikowa, przy czym typ relacji nie zależy od miejsca parentezy w zdaniu, ale od „sposobu operowania przez WP na strukturze WG" [Moroz 2010]. Pod względem budowy wyrażenia parentetyczne stanowią różnorodne strukturalnie ciagi; projekt klasyfikacji strukturalnej parentez ze składnikiem czasownikowym przedstawił Moroz [2010].

W składni strukturalnej parenteza $z$ czasownikiem jest opisywana jako wynik transformacji zdania wyjściowego. W modelu Jurija Apresjana [2012 (1986)] konstrukcja parentetyczna jest kompensacyjnym zjawiskiem składniowym, pozwalającym na niewypełnienie obligatoryjnej walencji leksemu: pierwsze miejsce walencyjne czasownika nie jest wypełnione, a druga walencję realizuje czasownik w zdaniu głównym, nie jest on jednak składniowo podporzadkowany czasownikowi parentetycznemu, tylko podporzadkowuje go tak jak jakikolwiek inny składnik w parentezie [Apresjan 2012, 25], por. Załóżmy, zatrzymacie się w Moskwie vs Załóżmy, że zatrzymacie się $w$ Moskwie.

W składni zależności Igora Mel'čuka w zdaniu z czasownikiem użytym parentetycznie relacja zależnościowa między czasownikiem a tzw. 
uzupełnieniem zdaniowym jest odwrócona względem użycia czasownika bez parentezy, por. $\mathrm{V} \leftarrow$ synt-P (parentetyczne) vs $\mathrm{V}-$ synt $\rightarrow \mathrm{P}$, por. Ja sčitaju, $\rightarrow$ čto položenie uxudšaetsja vs Položenie, ja sčitaju, $\leftarrow$ uxudšaetsja [Iordanskaja, Mel'čuk 2011, 121-122]. Przywołani autorzy wyróżnili trzy typy parentez czasownikowych, różniące się właściwościami syntaktycznymi, m.in. forma fleksyjna verbum, możliwościa pominięcia podmiotu czy miejscem struktury parentetycznej w zdaniu.

W składni dystrybucyjnej czasownikowe struktury parentetyczne uznaje się za jednostki operacyjne, tj. wyrażenia będące wynikiem przekształcenia parentetyzującego realizowanego na wyjściowej strukturze nieparentetycznej. Typy transformacji parentetyzujacych opisuje A. Moroz [2010], por. np. $\mathrm{V}_{\mathrm{p}}+\dot{\mathrm{Z}} \mathrm{e}+\left(\mathrm{S}_{1}+\mathrm{S}_{2}\right) \leftrightarrow \mathrm{S}_{1}+\mathrm{V}_{\mathrm{p}}+\mathrm{S}_{2}$, por.: Podkreślam, że jeszcze za wcześnie na gratulacje vs Podkreślam, jeszcze za wcześnie na gratulacje vs Jeszcze za wcześnie, podkreślam, na gratulacje.

Należy także odnotować ograniczenia gramatyczno-semantyczne nakładane na struktury z parentezą czasownikowa. Jeśli chodzi o semantyczne, parentezie podlegaja czasowniki stanów i czynności epistemicznych, komunikacji i percepcji, por. np. ang. think, believe, afraid; demonstrate, discover, declare; see, hear [zob. Iordanskaja, Mel'čuk 2011, 121], przy czym nie musi to być właściwość całych klas czy podklas wyrażeń - nie wszystkie czasowniki $z$ danych klas, w tym bliskoznaczne, moga w takim samym stopniu tworzyć struktury parentetyczne (por. ros. ob'jauljat' (-parent.) vs zajauljat' (+parent.) [Iordanskaja, Mel'čuk 2011, 122]. Z kolei ze względu na właściwości gramatyczne w parentetycznych strukturach czasownikowych istotnymi parametrami sa: forma czasu i trybu (por. podkreślam, _; dodam,_; dodajmy, _; zauważ, _; powiedzielibyśmy, _ ... vs *podkreślit, _; * będe dodawat, _; 'założyłem, _ ...), a także ograniczenia zwiazane $z$ ich współwystępowaniem z negacją (por. * nie podsumujmy, _; * nie załóżmy, _; * nie zauważ, itd. vs nie ukrywam, _; nie przecze,, itp.). Wskazane ograniczenia właściwości gramatyczno-syntaktycznych znajduja wyjaśnienie w funkcji parentezy (zob. niżej.)

\section{FUNKCJONALNE UJĘCIA PARENTEZY}

W teoriach funkcjonalnych parenteza jest ujmowana jako realizacja mówienia i opisywana na poziomie wypowiedzenia rozumianego jako zdanie $z$ przypisanym aktualnym rozczłonkowaniem. Ze względu na tę właściwość akcentuje się rolę parentezy w strukturze tematyczno-rematycznej wypowiedzenia (STR), zwłaszcza komentujaccy charakter struktur parentetycznych, a także ich operowanie na poziomie tzw. składni wypowiedzenia. Jako pierwszy w kategoriach funkcjonalnych, nie zaś formalno-syntaktycznych, ujmował parentezę W. Górny, który postulował przeniesienie opisu wypowiedzeń zestawionych ze składni (w ramach której stanowią zjawisko pograniczne i marginalizowane) do nauki o bu- 
dowie tekstu, ujmowanej jako osobna, pełnoprawna gałąz badań nad językiem (w przekonaniu, że „po przeniesieniu tych zjawisk ze składni ich ranga wzrośnie") [zob. Górny 1962].

\subsection{Parenteza jako komentarz do treści zdania}

Parentezę uznaje się za strukture językową operująca na STR. Stanowi ona osobna „taśmę dyskursu”, komentująca treści sądów; wyrażenia parentetyczne przeważnie pełnią funkcję dictów tematycznych, niekiedy zaś - rematów [zob. Bogusławski 1977]. Na „dwutekstowość" wypowiedzi $z$ parenteza jako dygresją ujawniajacca istnienie nadawcy tekstu głównego zwracał uwage Maciej Grochowski [1984]. Struktury parentetyczne reprezentuja poziom wypowiedzenia (realizacji języka), należą do „gramatyki” wypowiedzenia, czyli tzw. składni pragmatycznej (makroskładni, zgodnie $z$ ujęciem przedstawionym w: [Żabowska 2017]).

W tym ujęciu próba przyporządkowywania strukturom parentetycznym tzw. struktur bazowych jest zabiegiem nieuprawnionym, nie ma bowiem żadnych językowych dowodów na to, że w umyśle mówiącego struktura taka poprzedza strukturę parentetyczna; co najwyżej można opisywać relacje między dwoma typami zdań (z parentezą i bez); podobne stanowisko reprezentuje Zawadowski [1952] w odniesieniu do zdań względnych. Struktury parentetyczne sa nieredukowalne do schematów składniowych zależnościowych, odzwierciedlają nie relacje zachodzące w świecie, ale ustanawiane przez mówiącego; mają do spełnienia swoją rolę wyłącznie w momencie mówienia.

Warto podkreślić, że w ujęciu funkcjonalnym parenteza nie jest składnikiem redukowalnym. Przeciwnie, stanowi istotny $z$ punktu widzenia nadawcy komentarz do bieżącej wypowiedzi. Jako akt działania mówiącego na strukturze aktualnego wypowiedzenia sama nie podlega negacji. Ta funkcja parentezy należy tłumaczyć ograniczenia strukturalne (gramatyczno-syntaktyczne) nakładane na parentezę czasownikowa (zob. wyżej). Rozmaite czasowniki parentetyczne, niezależnie od ich formy gramatycznej, realizują zawsze czas teraźniejszy aktualny, por. Była, dodam, bardzo ładna, Była, dodajmy, bardzo ładna itd. Parenteza musi także wyrażać stwierdzenie pozytywne, w przeciwnym razie mielibyśmy do czynienia ze sprzecznościa, będaca wynikiem orzekania niedokonywania działań właśnie dokonywanych, por. *Była, nie zauważmy, bardzo ładna, *Maria, ukrywam, podoba mi sie vs Maria, nie ukrywam, podoba mi się.

\subsection{Prozodia parentezy}

Zenon Klemensiewicz [1953] uznaje intonację za wskaźnik składniowy wypowiedzenia zestawionego (na obligatoryjność wykładników wymawianiowych parentezy wskazuje także Komorowska [2001]). Przyjmuje się, 
że suprasegmentalnym wykładnikiem parentezy jest intonacja i pauzy [Grochowski 1986], parenteza na ogół nie jest akcentowana [Bogusławski 1977]. Cechy prozodyczne wyrażeń parentetycznych - takie jak niższy ton, brak akcentu, szybsze tempo, wydzielenie pauzami, brak możliwości kontrastowania eliminacyjnego - sa skorelowane $z$ funkcją dictów tematycznych, którą pełnią w wypowiedzeniu [Bogusławski 1977]. Szczegółowy opis prozodii parentezy przedstawiła Marzena Stępień [2014]. Badania eksperymentalne w tej dziedzinie przeprowadził Julian Skorek [2017].

\section{PARENTETYCZNOŚć A METATEKSTOWOŚć}

Na metatekstowość jako definicyjną właściwość parentezy wskazywał M. Grochowski [1983; 1984; 1986], który zaproponował schemat eksplikacji wypowiedzi z parentezą:

'Mówiąc to, że $\mathrm{S}_{1} \mathrm{P}_{1}$, mówię również o $\mathrm{S}_{1} \mathrm{P}_{1}$ (lub o czymś, co jest częścią $\mathrm{S}_{1} \mathrm{P}_{1}$ ) to, że $\mathrm{S}_{2} \mathrm{P}_{2}^{\prime}$ [Grochowski 1983],

odzwierciedlający fakt, że parenteza jest rezultatem świadomego działania nadawcy, który w ten sposób ujawnia samego siebie jako autora tekstu, a także to, że mówi coś o aktualnie użytym wyrażeniu językowym [Grochowski 1983]. Metatekstowa interpretację parentezy za M. Grochowskim przyjęli w swoich pracach A. Moroz [2010], M. Stępień [2014], K. Kleszczowa [2015].

W późniejszej pracy M. Grochowski [2007] odrzucił metatekstowe ujęcie parentezy. Powodem był $z$ jednej strony fakt, że ciagami wstawionymi parentetycznie do zdania moga być także wyrażenia o referencji pozajęzykowej czy semantycznie puste (np. przerywniki), z drugiej zaś to, że część wyrażeń metatekstowych nie może samodzielnie konstytuować parentezy. Należy przypomnieć, że wcześniej Anna Wierzbicka [1971] zwróciła uwage na to, że niektórym „czasownikom nawiasowym” (parenthetical verbs) można przypisać ramę metatekstowa, por. np. przyznaję, podkreślam, powtarzam, podczas gdy inne nie maja charakteru metatekstowego (nie zawieraja w strukturach semantycznych metapleonazmu „mówię”), por. np. sądzę, mam nadzieję, obawiam się. Między zakresami pojęć < parenteza> i <metatekst> zachodzi zatem - w ujęciu A. Wierzbickiej i następnie „późnego” Grochowskiego - relacja krzyżowania.

Najpoważniejszy problem w ustaleniu zakresów pojęć <parenteza> i <metatekst> stanowi aspekt komentujący, właściwy strukturom parentetycznym (a także - $z$ definicji - wyrażeniom metatekstowym). Dostrzeżenie tej właściwości jest argumentem za włączeniem parentezy do zjawisk $\mathrm{z}$ zakresu metatekstu. $Z$ drugiej jednak strony odmienność funkcji parentezy od metatekstowości, która jest właściwością elementów systemu, nie pozwala na zrównanie tych pojęć. 
Rozwiązania tego problemu należy, jak sądzę, upatrywać w rozróżnieniu dwóch odmiennych poziomów (i typów) komentarzy wypowiedzeniowych, tj. komentarzy metatekstowych oraz komentarzy mownych. Wyrażenia metatekstowe reprezentuja grupę pierwsza, tj. komentarzy (w szerokim sensie) metatekstowych, a wyrażenia parentetyczne należą do komentarzy mownych. Istota parentezy nie jest bowiem komentowanie aktualnie używanych wyrażeń w sposób właściwy elementom metatekstowym, zwłaszcza spójnikom, partykułom (por. np. 'to, co powiedziałem, to nie wszystko ...', 'powiedzieć o tym: $x$, to powiedzieć za mało'; 'mówię o tym: $x$, nie sądź, że więcej' itd.), ale jest ona wynikiem działania mówiącego na bieżącej wypowiedzi. Wprowadzając w tym miejscu jeszcze jedna opozycję, tj. narzędzi językowych i działań na tych narzędziach (w rozumieniu Bogusławskiego [2008b]), należy przyjąć, że metatekstowość jest właściwością narzędzi językowych, parentetyczność zaś - działań na tych narzędziach (należy do sfery realizacji języka). Ujmując tę kwestię jeszcze inaczej: wyrażenia metatekstowe sa leksykalnymi (systemowymi) komentarzami na temat bieżacego mówienia, parenteza natomiast - strukturalnym wyznacznikiem aktualnego działania mownego nadawcy.

Także cechy prozodyczne parentezy (zob. wyżej) nie sa właściwościami wyrażeń metatekstowych (ściślej: nieużytych parentetycznie wyrażeń metatekstowych).

\section{WYRAŻENIA PARENTETYCZNE}

W ujęciu J.O. Urmsona [1952] parenthetical verbs to czasowniki, które w 1. os. mogą być użyte w zdaniu parentetycznie (tylko niektóre $z$ nich dopuszczają użycia wyłącznie parentetyczne, np. conclude). W odróżnieniu od czasowników deskryptywnych nie przyjmują one form czasu present continuous, a jedynie present perfect, nie charakteryzuja bowiem stanu mentalnego mówiącego czy podejmowanych przez niego czynności mentalnych, ale wyrażają stosunek mówiącego do treści stwierdzenia (implikuja gotowość jego uznania), por. He is, I suppose, at home. Czasownikami parentetycznymi sa np. know, believe, rejoice, regret, conclude, suppose, guess, deduce, infer, presume, assume, expect, admit, predict. J.O. Urmson wskazuje także na istnienie przysłówków pełniących analogiczna funkcję, por. luckily, happily, consequently, presumably, certainly, undoubtedly, probably, possibly, a także na odpowiedniości zachodzace między tymi przysłówkami a czasownikami parentetycznymi, por. np. pary unfortunately - I regret, consequently - I infer (deduce), certainly - I know. Istotność wartości (formy i funkcji) 1. osoby zbliża czasowniki parentetyczne do czasowników performatywnych, w odróżnieniu jednak od performatywów wskazane właściwości czasowników parentetycznych dotyczą także pozostałych form paradygmatu (por. *I was believing) [zob. Urmson 1952]. 
Współcześnie odróżnia się wyrażenia inherentnie parentetyczne od użytych parentetycznie. Przyjmuje się także, że parentetyczność może być właściwościa poszczególnych jednostek leksykalnych lub całych klas semantyczno-funkcjonalnych wyrażeń. Może być ponadto rozpatrywana jako właściwość elementów systemu językowego bądź użycia wyrażeń.

\subsection{Parentetyczność jako właściwość elementów języka (systemu)}

Parentetyczność może być dystynktywną właściwością zarówno wyrażeń językowych, tzn. leksykalnych i operacyjnych jednostek języka, tzw. parentetycznych komentarzy metatekstowych [Żabowska 2009], parentetycznych jednostek języka [Stępień 2014], jak i całych klas - z definicji parentetyczne sa przerywniki [Śledź 2003, por. też sygnały fatyczne w: Ożóg 1990] i komentarze metatekstowe [Wajszczuk 2005].

Operacyjne jednostki języka inherentnie parentetyczne moga mieć charakter regularnych semantycznych lub asemantycznych przekształceń wyrażeń językowych. Przykładem parentetycznej operacji seman-

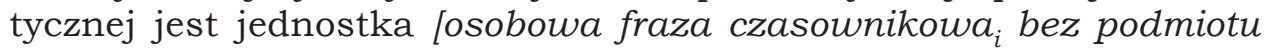
oznaczajaca wypowiedź lub działanie zmierzajace do stworzenia wypowiedzi] : [imiesłów przysłówkowy współczesny ], por. np. podsumować [coś] $\rightarrow$ podsumowujac, _ [Bogusławski, Danielewiczowa 2005, 347], a operacji asemantycznych - jednostki typu [jednostka inherentnie parentetyczna] : $\emptyset$, por. np. jak _, $: \varnothing$, np. jak sie domyślam, _ $\rightarrow$ domyślam się, _; czy że _, $: \emptyset$, np. że przypomne, _ $\rightarrow$ przypomne, _ [Stępień 2014, 130].

Z kolei leksykalnymi jednostkami parentetycznymi sa np. _, $b a$, ; _, ot, _; _, bagatela, _ (asyntagmatyki parentetyczne) [zob. Grochowski 2004; 2006], (tak), jak_, _; jak_, _ [Bogusławski 2008a], według [kogo], _; zdaniem [kogo], _ [Stępień 2014]; [jakoś] mówiąc, _ [Stępień 2014; Kubicka 2017; Żabowska 2020]. Stępień [2014] wyróżnia także inherentnie parentetyczne jednostki suprasegmentalne (prozodyczne), np. (tak), jak_,_.

Jak wskazywali Iordanskaja, Mel'čuk [2011], możliwość tworzenia struktur parentetycznych nie jest cechą uniwersalna wyrażeń quasi-synonimicznych, także w perspektywie ustalania ekwiwalencji międzyjęzykowej. $Z$ drugiej strony, produkty różnych parentetycznych jednostek operacyjnych moga przybierać taka samą formę, por. np. On, przypuszczam, wyjechat vs On, obawiam się, wyjechat [zob. Iordanskaja, Mel'čuk 1990; Danielewiczowa 2002, 285-290], por. On, obawiam się tego, wyjechał. Ponadto parentetyczne leksykalne jednostki języka moga mieć taki sam kształt jak produkty operacji parentetycznej, np. forma 2. os. trybu rozk. (por. powiedzmy, _ vs \{dodajmy / załóżmy\}, _, np. Przyjdę, powiedzmy, we wtorek vs Przyszedl, dodajmy, nie sam [por. Wołk 2007]) czy ciag $z$ forma imiesłowu na -ąc (por. prawdę mówiąc, _ vs \{dosadnie / delikatnie/ $w$ skrócie mówią̧\},_). 


\subsection{Parentetyczność jako właściwość realizacji systemu i użycia języka}

Wyrażenia użyte parentetycznie w wypowiedzeniu moga stanowić wynik: (a) realizacji inherentnie parentetycznych jednostek operacyjnych, np. podsumowujac, _; dodajmy, _, lub (b) użycia w postaci tzw. wtracenia wyrażeń językowych nienależących do klasy wyrażeń inherentnie parentetycznych, np. On, oczywiście, wyjechał. Oba wskazane zbiory wyrażeń maja charakter otwarty, przy czym klasę (a) tworzy przewidywalny zestaw wyrażeń o wspólnych cechach semantyczno-funkcjonalnych, a klasę (b) może reprezentować w zasadzie dowolne wyrażenie. W wypadku wyrażeń językowych inherentnie parentetycznych opozycja podlega neutralizacji.

Tabela. Parentetyczność jako wlaściwość wyrażeń językowych

\begin{tabular}{|c|c|c|c|}
\hline \multicolumn{4}{|c|}{ parentetyczność jako cecha narzędzi językowych } \\
\hline $\begin{array}{c}\text { klasy } \\
\text { semantyczno- } \\
\text {-syntaktyczne }\end{array}$ & \multicolumn{3}{|c|}{ inherentnie parentetyczne jednostki języka } \\
\hline \multirow{2}{*}{$\begin{array}{l}\text { przerywniki, } \\
\text { komentarze } \\
\text { metatekstowe }\end{array}$} & \multirow{2}{*}{ leksykalne } & \multicolumn{2}{|c|}{ operacyjne } \\
\hline & & semantyczne & asemantyczne \\
\hline $\begin{array}{l}\text { np. _, prawda, } \\
\text {-, tego, } \\
\quad \text {, wiesz, }\end{array}$ & $\begin{array}{c}\text { np. _, bagatela, } \\
\text { _, ba, } \\
\text {, ot, } \\
\text { jak_, } \\
\text { [jakośs mówiac, }\end{array}$ & $\begin{array}{c}\text { np. osobowa fraza } \\
\text { czasownikowa }{ }_{i} \text { bez } \\
\text { podmiotu oznacza- } \\
\text { jaca wypowiedź lub } \\
\text { działanie zmierza- } \\
\text { jace do stworzenia } \\
\text { wypowiedzi } \\
\text { imiesłów przysłów- } \\
\text { kowy współczesny }\end{array}$ & $\frac{\begin{array}{c}\mathrm{np} . \\
j a k_{-},-\end{array}}{\varnothing}$ \\
\hline \multicolumn{4}{|c|}{ parentetyczność jako cecha działań na narzędziach językowych } \\
\hline $\begin{array}{c}\text { klasy } \\
\text { semantyczno- } \\
\text {-funkcjonalne }\end{array}$ & \multicolumn{3}{|c|}{ różne wyrażenia językowe } \\
\hline $\begin{array}{c}\text { realizacja } \\
\text { jednostek } \\
\text { systemu }\end{array}$ & \multicolumn{3}{|c|}{ użycie parentetyczne } \\
\hline $\begin{array}{c}\text { np. podsumowując } \\
\text { domyślam sie } \\
\text { przypomne }\end{array}$ & \multicolumn{3}{|c|}{$\begin{array}{c}\mathrm{np} . \\
\text {, oczywiście, } \\
\text { _, dziś, }\end{array}$} \\
\hline
\end{tabular}

Źródło: opracowanie własne. 


\section{LEKSYKALIZACJA I GRAMATYKALIZACJA WYRAŻEŃ PARENTETYCZNYCH: POWSTAWANIE WYRAŻEŃ I KLAS WYRAŻEŃ METATEKSTOWYCH}

W perspektywie diachronicznej rozwój struktur językowych jest potwierdzeniem właściwego parentezie aspektu działania mownego. Użycia parentetyczne były podstawą wytworzenia się podklas wyrażeń metakomentujacych, głównie partykuł i komentarzy metatekstowych. Liczne podklasy partykuł [zob. SGPP] powstały przez zerowanie autoreferującej parentezy [zob. Kleszczowa 2015]. Pierwotne konstrukcje przysłówkowo-czasownikowe $z$ czasownikiem $\mathrm{w}$ formie funkcjonalnie teraźniejszej (1. os. cz. ter. lub imiesłów na -ac, -wszy, -łszy), np. powiadam po prostu, kłade za prawdę, wiem za pewne, na przykład biorac, właśnie mówiąc, w wyniku elizji redundantnej treści 'mówię, że mówię' przekształciły się w wyrażenia metatekstowe: po prostu, zaprawdę, zapewne, na przykład, właśnie. Na to, że nie jest to proces uniwersalny - tylko określone typy semantyczne parentez daja określone podtypy semantyczne partykuł, wskazywała Krystyna Kleszczowa [2015, 47-55]. Ze struktur pierwotnie parentetycznych wytworzyły się także komentarze metatekstowe, por. np. prawdę mówiąc, nawiasem mówiac; że [przypomne], _; by [przypomnieć], _; jak [sądze] [por. też Weiss 2005]. Wynikiem tekstowego (wypowiedzeniowego) mechanizmu parentezy są zarówno zleksykalizowane wyrażenia, jak i klasy funkcjonalne. W rozwoju diachronicznym m.in. ze zhierarchizowanych struktur składniowych $z$ parenteza wytworzył się metatekst.

W perspektywie gramatykalizacji ujmuje się przejście wyrażeń z poziomu przedmiotowego do wyrażeń tzw. gramatycznych (funkcyjnych, $\mathrm{w}$ tym metatekstowych), por. np. tzw. przysłówki epistemiczne, np. niewatpliwie, prawdopodobnie; quasi-imiesłowy, np. podsumowujac, [jakoś] mówią; wyrażenia „ekwiwalentne illokucyjnie”, np. jak (sądzę, twierdzę), _; że (powiem, podsumuję), _; „celowe” by (podsumować), _; „przyczynowe", np. dla, gwoli (podsumowania, przypomnienia),_. Sa one skutkiem zmian składniowo-funkcjonalnych i kategorialnych wyrażeń używanych parentetycznie.

W teorii gramatykalizacji zwraca się uwage na to, że tzw. czasowniki słabe (fr. verbes faibles; epistemiczne, parentetyczne) maja tendencję do desemantyzacji i przekształcania się w wykładniki dyskursu (discourse markers), np. fr. on dit que - on dit - dit-on [Pop 2009], por. pol. powiedzmy. Bernd Heine [2013] wyrażenia parentetyczne jako należace do klasy wyrażeń tetycznych (theticals) ujmuje w perspektywie kooptacji (cooptation) jako operacji spontanicznej, która nie prowadzi do zmiany językowej; w wyniku zmian diachronicznych tak używanych wyrażeń powstają rozmaite wykładniki pragmatyczne (pragmatic markers), np. ang. I mean, look, what else, indeed.

Przedmiotem uwagi w niniejszym artykule były właściwości systemowe struktur parentetycznych. Osobna sprawa jest funkcjonowanie 
tych struktur w różnego typu tekstach, w szczególności ich funkcje stylistyczne, np. w prozie artystycznej [zob. Bąba, Mikołajczak 1973; Bąba, Mikołajczak 1975], w wypowiedziach prasowych [Marcjanik 1978] czy w autorskich idiolektach [Ciołek 2008], a także inne funkcje tekstowe, np. wprowadzania eufemizmów [Dąbrowska 1991].

\section{Bibliografia}

J.D. Apresjan, 2012, Informacja składniowa $w$ słowniku jednojęzycznym, tłum. A. Sobotka, P. Sobotka [w:] Z. Zaron (red.), Z warsztatu leksykografa, Warszawa, s. 13-40; pierwodruk [1986] w: „Linguistische Arbeitsberichte” 54-55, s. $88-116$.

S. Bąba, S. Mikołajczak, 1973, Parenteza we współczesnej prozie polskiej (klasyfikacje i funkcje), „Studia Polonistyczne” 1, s. 7-31.

S. Bąba, S. Mikołajczak, 1975, Funkcje stylistyczne parentezy $w$ „Pamiętniku starego subiekta” w „Lalce” B. Prusa, „Studia Polonistyczne” 2, s. 59-69.

A. Bogusławski, 1977, Problems of the Thematic-Rhematic Structure of Sentences, Warszawa.

A. Bogusławski, 2008a, O pewnym wykładniku równoważności lokucyjnej [w:] B. Wiemer, V.A. Plungjan (red.), Lexikalische Evidenzialitäts-Marker in slavischen Sprachen (Wiener Slawistischer Almanach Sonderband 72), MünchWien, s. 6-93.

A. Bogusławski, 2008b, Semantyka, pragmatyka: leksykografa głos demarkacyjny, Warszawa.

A. Bogusławski, M. Danielewiczowa, 2005, Verba polona abscondita. Sonda słownikowa III, Warszawa.

A. Ciołek, 2008, Funkcja wyrażen parentetycznych w listach C.K. Norwida, „Język Polski” z. 2, s. 116-121.

M. Danielewiczowa, 2002, Wiedza i niewiedza. Studium polskich czasowników epistemicznych, Warszawa.

A. Dąbrowska, 1991, Tekstowe sygnały wprowadzania eufemizmów, „Biuletyn PTJ" VLVI, s. 105-109.

W. Górny, 1962, Zestawienie - czy tylko kategoria składniowa?, „Pamiętnik Literacki" 53/1, s. 181-193.

M. Grochowski, 1983, Metatekstowa interpretacja parentezy [w:] T. Dobrzyńska, E. Janus (red.), Tekst i zdanie: zbiór studiów, Wrocław, s. 247-258.

M. Grochowski, 1984, Składnia wyrażeń polipredykatywnych: zarys problematyki [w:] Z. Topolińska (red.), Gramatyka współczesnego języka polskiego: składnia, Warszawa, s. 213-299.

M. Grochowski, 1986, Parenteza i metarečenica, „Južnoslovenski filolog” 42, Beograd, s. 1-8.

M. Grochowski, 2004, Jednostki leksykalne o postaci ba jako komentarz metatekstowy, „Poradnik Językowy” z. 2, s. 18-26.

M. Grochowski, 2006, Parentetyczne ot jako komentarz metatekstowy: wprowadzenie do opisu, „LingVaria” 1(1), s. 49-56.

M. Grochowski, 2007, Partykuły, parenteza a wyrażenia metatekstowe, „Z polskich studiów slawistycznych" seria XI, Językoznawstwo, Warszawa, s. 69-74. 
B. Heine, 2013, On discourse markers: Grammaticalization, pragmaticalization, or something else?, „Linguistics” 51/6, s. 1205-1247.

L. Iordanskaja, I. Mel'čuk, 1990, Semantics of Two Emotion Verbs in Russian: BOJAT'SJA 'to be afraid' and NADEJAT'SJA 'to hope', „Australian Journal of Linguistics" 10/2, s. 307-357.

L. Iordanskaja, I. Mel'čuk, 2011, Mlocutive Parenthetical Verbs in Russian [w:]: I. Boguslavsky, L. Wanner (red.), Proceedings of the 5th International Conference on Meaning-Text Theory (Barcelona, September 8-9), Barcelona, s. 120-133.

S. Jodłowski, 1976, Podstawy polskiej składni, Warszawa.

Z. Klemensiewicz, 1951, Problematyka składniowej interpretacji stylu, „Pamiętnik Literacki" 42/1, s. 102-157.

Z. Klemensiewicz, 1953, Zarys składni polskiej, Warszawa.

K. Kleszczowa, 2015, U źródeł polskich partykut: derywacja funkcjonalna, przemiany, zaniki, Katowice.

E. Komorowska, 2001, Leksykalno-semantyczne wykładniki parentezy postpozycyjnej w języku polskim i rosyjskim, Szczecin.

A. Krasnowolski, 1897, Systematyczna składnia języka polskiego, wydana z zapomogi Kasy Pomocy Naukowej imienia Dr. Mianowskiego, Warszawa.

E. Kubicka, 2017, Jak mówimy jakoś mówiąc? Formalne $i$ semantyczne właściwości adwerbialnych uzupełnień quasi-imiesłowowego mówiąc, „LingVaria” (1)23, s. 99-113.

W. Makarski, 1971, O zestawieniu z parenteza, „Roczniki Humanistyczne KUL-u” 19/1, s. 351-370.

M. Marcjanik, 1978, Wtracenia nawiasowe we współczesnej prasie, „Poradnik Językowy" z. 6, s. 261-268.

A. Moroz, 2010, Parenteza ze składnikiem czasownikowym we współczesnym języku polskim, Toruń.

K. Ożóg, 1990, Leksykon metatekstowy współczesnej polszczyzny mówionej. Wybrane zagadnienia, Kraków.

L. Pop, 2009, Quelles informations se pragmatisent? Le cas des verbes plus au moins marquers, "Revue roumaine de linguistique” 1-2: Gramaticalizare şi pragmaticalizare în limba română, s. 161-172.

SGPP: M. Grochowski, A. Kisiel, M. Żabowska, 2014, Słownik gniazdowy partykut polskich, Kraków.

J. Skorek, 2015, Parenteza $w$ dyskursie lingwistycznym wielosuprematycznych wypowiedzen oznajmujacych (badanie eksperymentalne), „Annales UMCS”, Sectio FF, 33, s. 81-94.

M. Stępień, 2014, Wyrażenia parentetyczne $w$ strukturze wypowiedzi: właściwości semantyczne, składniowe, prozodyczne, Warszawa.

A. Śledź, 2003, Przerywnik czy wykrzyknik? Analiza składniowa i semantyczna pewnych użyć słów uważanych za wulgarne, „Poradnik Językowy” z. 9, s. 69-74.

J.O. Urmson, 1952, Parenthetical Verbs, „Mind” 61 (244), s. 480-496.

J. Wajszczuk, 2005, O metatekście, Warszawa.

D. Weiss, 2005, Nowe przyimki o pochodzeniu imiesłowowym? [w:] M. Grochowski (red.), Przysłówki i przyimki: studia ze składni i semantyki języka polskiego, Toruń, s. 177-207.

A. Wierzbicka, 1971, Metatekst w tekście [w:] M.R. Mayenowa (red.), O spójności tekstu, Wrocław, s. 105-121. 
M. Wołk, 2007, Co mówimy, mówiąc powiedzmy?, „Poradnik Językowy” z. 1, s. $5-19$.

H. Wróbel, 1975, Składnia imiesłowów czynnych we współczesnej polszczyźnie, Katowice.

L. Zawadowski, 1952, Zagadnienia teorii zdań względnych, Wrocław.

M. Żabowska, 2009, Wyrażenia metatekstowe $w$ funkcji parentezy [w:] M. Skarżyński, A. Czelakowska (red.), Język z różnych stron widziany, Kraków, s. $157-166$.

M. Żabowska, 2017, Makroskładnia-wypowiedzeniowe struktury syntaktyczne, "Linguistica Copernicana” 14, s. 71-87.

M. Żabowska, 2020, Szyk wyrażeń jako cecha dystynktywna w polu komentarzy metatekstowych: [Adv] mówiąc, _ vs. mówiąc [Adv], „, „Poradnik Językowy” z. 9, s. 21-37.

\section{Parenthesis and metatext}

\section{Summary}

This paper discusses the question of correlations between the terms 'parenthesis' and 'metatext'. To this end, it presents the most significant (syntactic and functional) concepts of parenthesis and issues related to the metatextuality of parenthetical structures. Apart from overview sections, the paper puts forward the author's own proposition for distinguishing the scope of the term 'parenthesis' from that of 'metatext' ('parentheticality' vs 'metatextuality', respectively). It assumes that the essence of parenthesis, unlike metatextuality, is not to comment on the expressions used currently; instead, it is an effect of the speaker's actions performed on the present statement (cf. the opposition: language tools and actions using such tools). The paper presents also organisation of language expressions (both individual units and entire classes) by their capability to occur in parenthesis (cf. inherently parenthetical elements of the system vs parenthetical usages of language expressions) and fulfil metatextual functions. It also takes up the question of the influence of parenthetical structures on changes in language: with reference to the development of metatextual expressions and their classes as a result of lexicalisation and grammaticalisation processes.

Keywords: parenthesis - metatext - parenthetical expressions

Trans. Monika Czarnecka 